\title{
SURVEY OF HEALTHY LIVING PATTERNS OF STUDENTS OF HEALTH FKIP UNDANA STUDENTS IN THE COVID-19 PANDEMIC
}

\author{
Al Ihzan Tajuddin ${ }^{1}$, Yudabbirul Arif ${ }^{2}$ Erwin S Neolaka ${ }^{3}$, Ronald Dwi Ardian \\ Fufu $^{4}$, Michael Johannes Hadiwijaya Louk ${ }^{5}$ \\ ${ }^{12345}$ Physical Education, Health And Recreation Department, Faculty of Education and Teachers \\ Training, Universitas Nusa Cendana, Indonesia
}

\section{Info Artikel}

Article History :

Received : November 2021

Revised : December 2021

Accepted : December 2021

Available online :

December 2021

Keywords:

Covid-19, Healthy lifestyle, Physical Education Sport,

\begin{abstract}
Abstrak
At this time the phenomenon that is happening right now is in a new lifestyle, which as we understand it about healthy living, keeping a distance and so on can be called the new normal, because the main reason is the coronavirus. The problem is based on the fact that it can be seen that the lifestyle of many students is not healthy, so a survey related to the lifestyle of students is carried out. This research is a descriptive research using a survey method. The population in this study were Physical Education and Health Students at Nusa Cendana University. The sample in this study used simple random sampling; the research sample was 80 students from the Physical Education and Health Center of Nusa Cendana University. By giving a questionnaire to students who are the subjects in the research. This research instrument uses a questionnaire in the form of a written statement given through a google form to the respondent. Based on the results of data analysis and discussion, it can be concluded that the healthy lifestyle of FKIP Undana Penjaskesrek students during the COVID-19 pandemic was in the "never" category by $15 \%$ (6 students), "rarely" by 35\% (14 students), " often" by 38\% (15 students), "often" by $13 \%$ (5 students). Based on the average score, which is 139.58 , the healthy lifestyle of FKIP Undana Penjaskesrek students is in the "Frequent" category. In the sense that the FKIP Undana Penjaskesrek students during the covid 19 period often apply a healthy lifestyle.
\end{abstract}




\section{INTRODUCTION}

A healthy lifestyle is a lifestyle by paying attention to certain factors that affect health, including food and exercise, (Rahmawati, 2020). As it is said that it is very important to have a healthy lifestyle to maintain and maintain body fitness. Healthy lifestyles are patterns related to a person's efforts or activities to maintain and improve their health (Notoatmodjo, 2018). As has been explained, a healthy lifestyle must be done in order to improve health.

A healthy lifestyle is a lifestyle that pays attention to all aspects of health conditions (Isnayati et al., 2020). Starting from the food, drinks, nutrition consumed and our daily behavior. Whether it's in an exercise routine that will certainly maintain health conditions and will also avoid everything that can cause disease for our bodies (Nopiyanto et al., 2020). The conclusion that can be understood is that a healthy lifestyle is to fortify the body to avoid disease. The definitions above can be concluded that a healthy lifestyle is a lifestyle related to one's efforts to maintain and improve health. One of the most valuable assets for everyone is the fulfillment of health (Arif, 2020). As said this health is an important thing that is an asset in the body.

Health is a healthy state both physically, mentally and socially that can enable everyone to live productively in everyday life, such as work, school and so on. According to the Regulation of the Minister of Health of the Republic of Indonesia No. 12 of 2017 Article 1 paragraph 1 "immunization is an effort to actively cause/increase a person's immunity to a disease so that if one day he is infected with the disease he will not get sick or only experience mild illness." (Permenkes, 2017). Body health will be achieved if you can apply a healthy lifestyle to the maximum (Saputra, 2020). A healthy lifestyle is a pattern related to one's efforts to maintain and improve health that must be applied through the learning process, both from school, family and community.

At this time the phenomenon that is happening right now is in a new lifestyle, which as we understand it about healthy living, keeping a distance and so on can be called the new normal, because the main reason is the coronavirus. (Intan et al., 2021). This virus is a type of virus that can be said to be new, so the vaccine is still being researched and has not been found. The transmission is easy and the risk level is very high, so we need to be vigilant. For transmission, it can occur from several reasons, such as from mucus, coughing, phlegm, touching hands and so on (Setiati \& Azwar, 2020). It is this virus that is realized that is very dangerous for humans and can even cause death, therefore we must try to suppress it so that this virus does not spread.

Health education needs to be applied maximally to students (Wulandari, 2020). Health education is an effort to make students aware of healthy living such as maintaining cleanliness, regulating diet, exercising, with health education about healthy lifestyles it is hoped that students can understand and apply healthy lifestyles in daily life, among others, 1. Maintain cleanliness such as bathing twice a day, brushing teeth and so on, 2. Keeping the environment clean such as throwing garbage in its place, 3. Eating food by paying attention to food hygiene and nutrition in food, 4. Exercising regularly and regularly to improve fitness to be healthy by using fit formula. Health education is an effort to make students aware of healthy living such as maintaining cleanliness, regulating diet, 
exercising (Yulinda Sari et al., 2020). The problem from this research is an important thing to know and to be able to answer the existing problems, namely to find out how the picture of the healthy lifestyle of Fkip Undana Penjaskesrek students during the covid 19 pandemic.

The novelty of the research that I conducted is a very important research considering that there is currently a pandemic so that the survey conducted can see in general how the level of student life patterns is currently. Eating habits, including lifestyles, have also changed, including students who are currently pursuing formal education at universities, especially for students with specialization in nutrition who have previously been provided with knowledge about consumption habits in accordance with the principles of balanced nutrition (Noviasty \& Susanti, 2020). The pattern of life carried out by students depends on whether the education itself runs so that this will be well patterned later. When compared with similar research, this study uses the latest theory and uses Mendeley as an application that combines various journals so that it is easy to quote here.

And this article uses a survey method that can see as a whole about how students carry out a healthy lifestyle whether it has been embedded in themselves or not.

The thing to be achieved in this research is to find out the healthy lifestyle of the penjaskesrek fkip undana students so that they can see how their body condition is during the current pandemic.

\section{METHODS}

This research is a descriptive research using a survey method.
Descriptive research is research that only really describes what is or occurs in a certain field, field and area (Arikunto, 2013).

Population is a generalization area consisting of: objects that have certain quantities and characteristics determined by researchers to be studied and then drawn conclusions (Sugiono, 2016). The population in this study were students of Physical Education and Health at the University of Nusa Cendana. The research sample is part or representative of the population under study (Sugiyono, 2017). The sample in this study used simple random sampling; the research sample was selected from as many as 80 students from Penjaskesrek University of Nusa Cendana.

The data collection technique that will be used is by giving questionnaires to students who are the subjects of the research. The mechanism is as follows:

- The researcher looks for data on the 3rd and 5th semesters of physical education and health education students

- Researchers determine the number of students who are the subject of research.

- Researchers distribute questionnaires to respondents.

- Next, the researcher collected the questionnaire and did a transcript of the results of filling out the questionnaire.

- After obtaining research data, the researcher draws conclusions and suggestions.

Validity, reliability, level of difficulty, discriminatory power and distractors are important things that must be considered by researchers so that the instruments made are good, so that they 
can be used in and produce good data as well.(Arifin, 2017). This research instrument uses a questionnaire in the form of a written statement given through a google form to the respondent.

The factors in this study that are related include: 1. Maintaining cleanliness with indicators (body, clothes, environment) 2. Healthy food with indicators (food quality, eating habits, drinking habits). 3. Regular way of life with indicators (sleep, recreation, rest,). 4. Improve data on body resistance and physical opportunities with indicators (vaccination, exercise) 5. Avoiding disease by indicators (alcohol, drugs, smoking, and coughing without covering your mouth). 6. Increased intelligence and spirituality with indicators (increasing knowledge),7. Equip facilities that guarantee a healthy life with indicators (PPPK). 8. health check with indicator (time of body health examination).

Before the trial, the researcher conducted expert validation/testing of the instrument. Validation is carried out by expert lecturers. The validation lecturers in this study were Lecturers from the Penjaskesrek Study Program and the Outof-School Education Study Program, FKIP Undana. The trial was carried out on 40 semester 9 students of Physical Education and Health, FKIP Undana. The trial was carried out in semester 9 because it had the same characteristics as the subject to be studied, both from the conditions during the COVID-19 pandemic, for example, the lecture process was conducted online.

The data obtained in this study will be analyzed using descriptive analysis. After all the data has been collected, the next step is to analyze the data so that a conclusion can be drawn. The data analysis technique in this study uses descriptive quantitative data analysis techniques

\section{RESULT}

The results of the analysis are presented as follows: Statistical descriptive of research data on healthy lifestyles of students from Penjaskesrek FKIP Undana obtained the lowest score (minimum) 114, highest score (maximum) 163, average (mean) 139.58, median (median) 139.50 , frequently occurring value (mode) 139, standard deviation (SD) 11.609 .

1. Healthy Lifestyle of FKIP Penjaskesrek Students

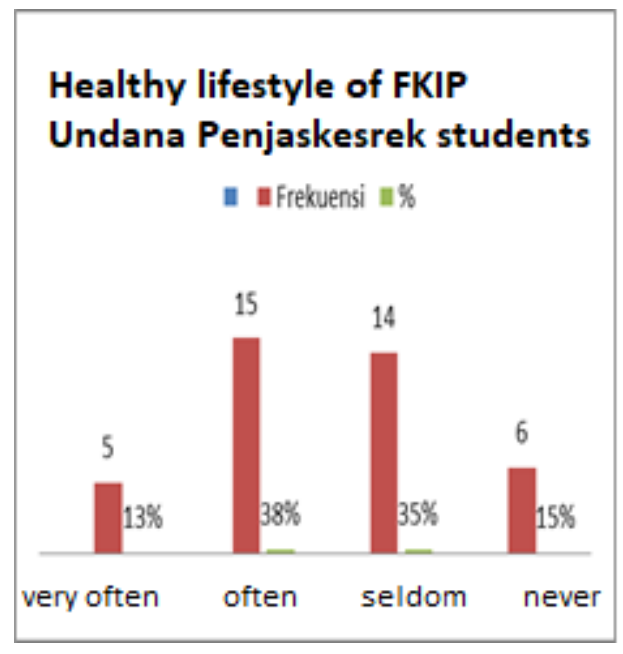

Figure 1. Bar Chart of Healthy Lifestyles for Undana Penjaskesrek FKIP Students During the Covid-19 Pandemic.

The picture above shows that the healthy lifestyle of FKIP Undana Penjaskesrek students during the covid 19 pandemic was in the "never" category by $15 \%$ (6 students), "rarely" by 35\% (14 students), "often" by 38\% ( 15 students), "often" by $13 \%$ (5 students). Based on the average score, which is 139.58 , the healthy lifestyle of FKIP Undana Penjaskesrek students is in the "Good" category. 
2. Maintain cleanliness

Factors for maintaining cleanliness obtained the lowest score (minimum) 20, highest score (maximum) 32, average (mean) 26.90, median (median) 27.00, frequently occurring value (mode) 26, standard deviation (SD) 2.907 .

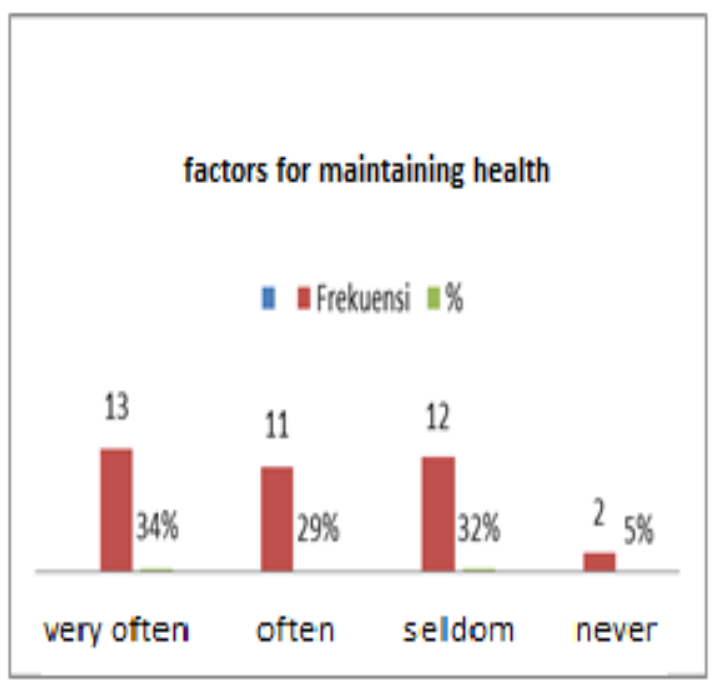

Figure 2. Bar Diagram of Maintaining Cleanliness

Based on the picture above, it shows that the factor of maintaining cleanliness is in the category of "never" by 18\% (7 students), "rarely" by 35\% (14 students), "often" by $40 \%$ (16 students), "often" by $8 \%$ (3 students). Based on the average score, which is 27 , the healthy lifestyle of FKIP Undana Penjaskesrek students is in the "Frequent" category..

\section{3. healthy food}

Based on healthy food factors, the lowest score (minimum) is 20 , the highest score (maximum) is 36 , the mean (mean) is 29.90 , the mean (median) is 30.00 , the value that occurs frequently (mode) is 30 , the standard deviation (SD) is 3,327.

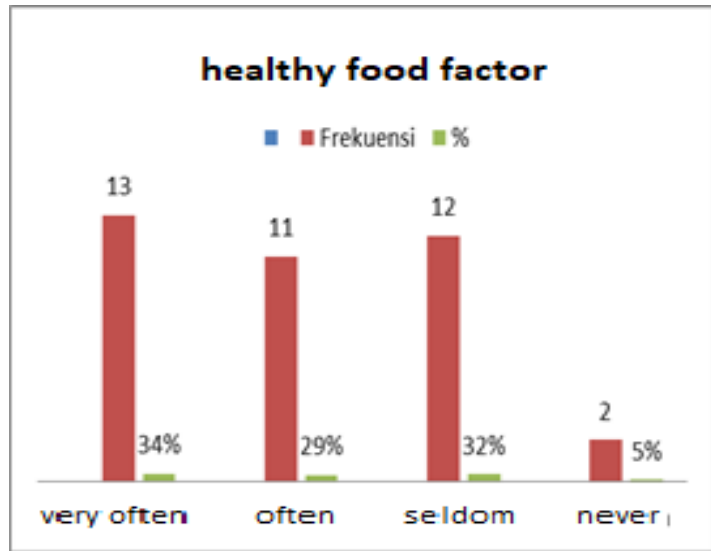

Figure 3. Bar Diagram of healthy food factors

Figure 3 above shows that the healthy food factors are in the "never" category by $13 \%$ (5 students), "rarely" by $32 \%$ (12 students), "often" by 29\% (11 students), "very often" by 34\% (13 students). Based on the average score, which is 30, the healthy lifestyle of FKIP Undana Penjaskesrek students is in the "Frequent" category.

\section{Orderly Way of Life}

Based on the factors of a regular way of life, the lowest score (minimum) is 11 , the highest score (maximum) is 20 , the mean (mean) is 16.50 , the mean (median) is 17.00 , the value that occurs frequently (mode) is 17, the standard deviation ( SD) 1,769 .

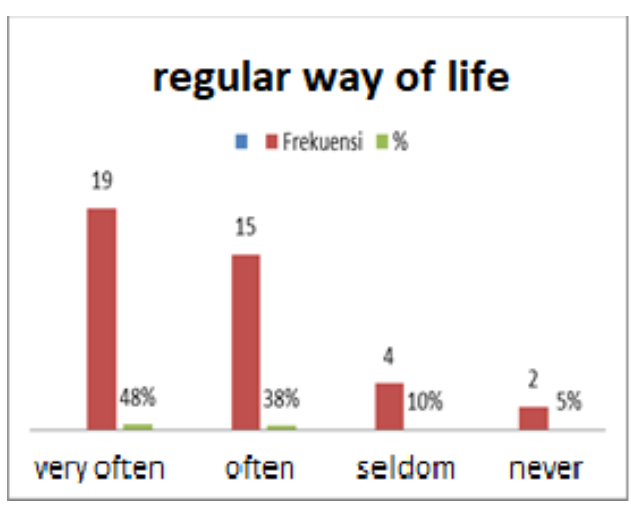

Figure 4. Bar chart of the factors of an orderly way of life 
The picture above shows that the healthy lifestyle of FKIP Undana Penjaskesrek students during the covid 19 pandemic, healthy food factors are in the "never" category by $13 \%$ (5 students), "rarely" by $20 \%$ (8 students), "often" by $53 \%$ (21 students), "often" by 15\% (6 students). Based on the average score, which is 17 , the healthy lifestyle of FKIP Undana Penjaskesrek students is in the "Frequent" category.Daya Tahan Tubuh Dan Kesehatan Jasmani

5. About factors to increase endurance and physical health

The lowest score (minimum) is 4 , the highest score (maximum) is 12 , the mean (mean) is 9.88, the mean (median) is 10.00 , the most frequent value (mode) is 9 , the standard deviation (SD) is 1.870 .

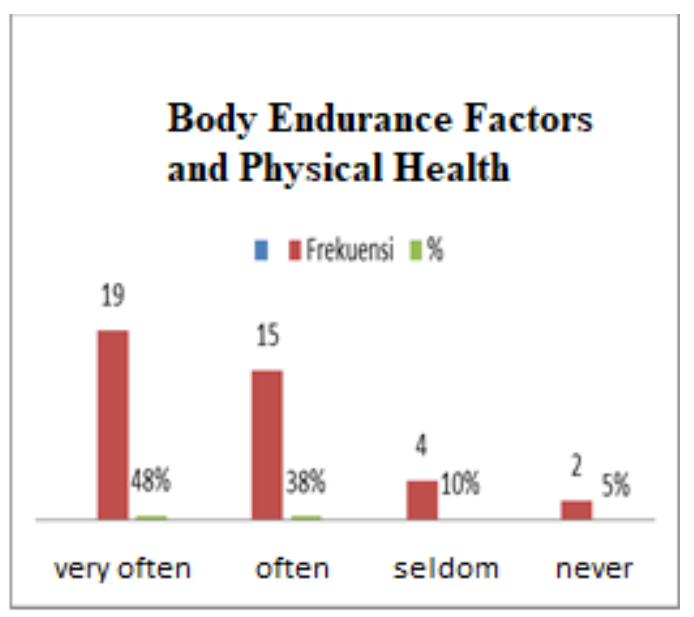

Figure 5. Bar Diagram of Body Endurance Factors and Physical Health

The picture above shows that the healthy lifestyle of FKIP Undana Penjaskesrek students during the COVID19 pandemic, the immune and physical health factors are in the "never" category by $5 \%$ ( 2 students), "rarely" by $10 \%$ (4 students), "often" is $38 \%$ (15 students), "often" is $48 \%$ (19 students). Based on the average score, which is 10 , the healthy lifestyle of the students of Physical
Education and Health Fkip Undana factors in endurance and physical health in the "Frequent"

\section{Category occurrence of the disease}

Statistical descriptive of research data on factors to avoid the occurrence of disease obtained the lowest score (minimum) 15, highest score (maximum) 27 , average (mean) 21.43, median value (median) 22.00, value that occurs frequently (mode) 22 , standard deviation (SD) 2.459 .

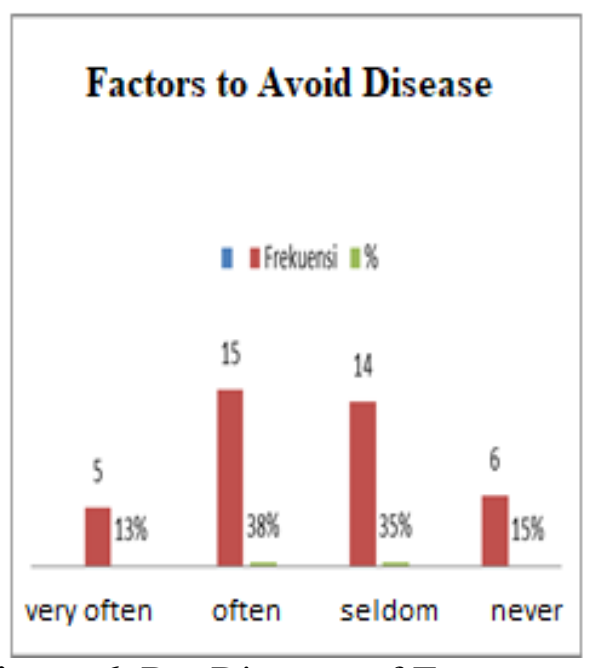

Figure 6. Bar Diagram of Factors to Avoid Disease

The picture above shows that the disease avoidance factor is in the "never" category of $13 \%$ (5 students), "rarely" by $23 \%$ (9 students), "often" by 50\% (20 students), "often" by 15\% (6 students). Based on the average score, which is 22 , the healthy lifestyle of FKIP Undana Penjaskesrek students is a factor in avoiding "frequent" disease.

\section{Increase Intelligence and Spirituality}

Data from research on healthy lifestyles of Fkip Undana Penjaskesrek students during the covid 19 pandemic based on factors that increase intelligence and spirituality, the lowest score 
(minimum) 4, highest score (maximum) 12 , average (mean) 10.18, median value (median) 11.00, frequently occurring value (mode) 11, standard deviation (SD) 1.781 .

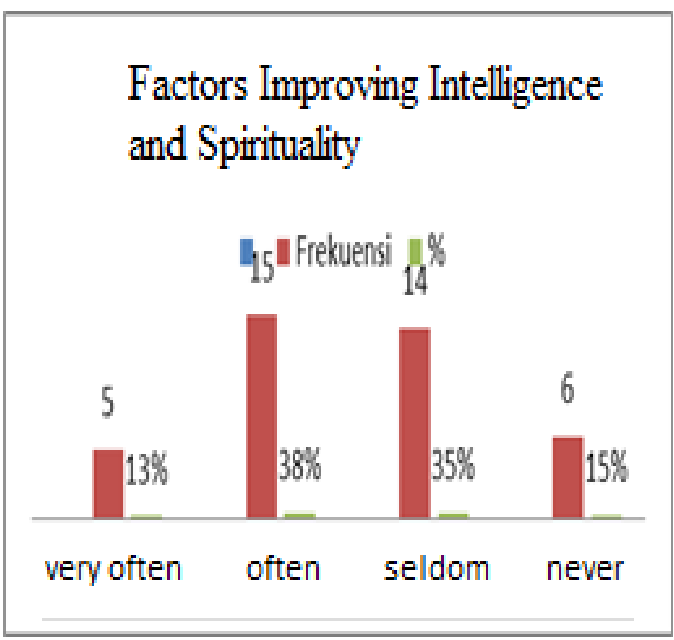

Figure 7. Bar Chart of Factors Improving Intelligence and Spirituality

Based on the table above, it shows that the healthy lifestyle of FKIP Undana Penjaskesrek students during the COVID19 pandemic, the factors that increase intelligence and spirituality are in the "never" category by 5\% (2 students), "rarely" by $5 \%$ (2 students), "often" is $38 \%$ (15 students), "often" is 53\% (21 students). Based on the average score, which is 11 , the healthy lifestyle of the Fkip Undana Penjaskesrek students is a factor in avoiding the disease "often".

\section{Increase Intelligence and Spirituality}

Data from research on healthy lifestyles of FKIP Undana Penjaskesrek students during the COVID-19 pandemic based on the factors that ensure healthy living, the lowest score (minimum) was 10, the highest score (maximum) 24, the average (mean) 19.33, the median score (median) ) 19.00, frequently occurring value (mode) 17, standard deviation (SD) 3.347 .

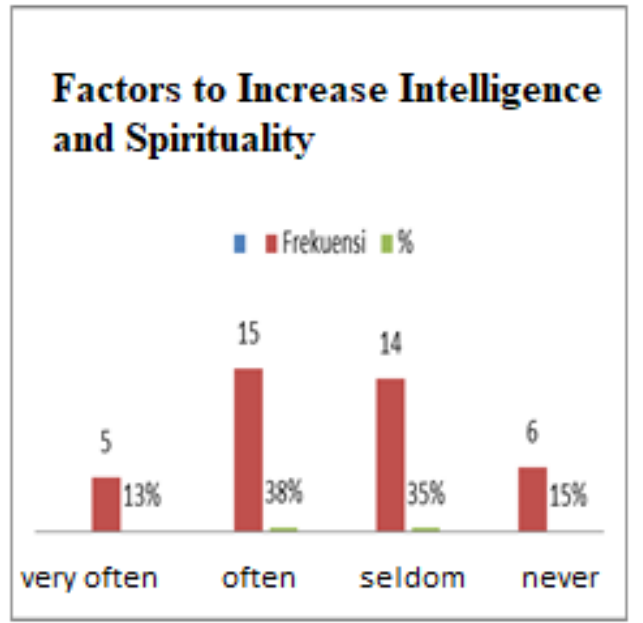

Figure 8. Bar Diagram of Factors to Increase Intelligence and Spirituality

Based on the picture above, it shows that the healthy lifestyle of FKIP Undana Penjaskesrek students during the COVID-19 pandemic, the factors that increase intelligence and spirituality are in the "never" category by 10\% (4 students), "rarely" by $18 \%$ (7 students), " often" by $43 \%$ (17 students), "often" by 30\% (12 students). Based on the average score, which is 20, the healthy lifestyle of FKIP Undana Penjaskesrek students is a factor in avoiding "frequent" disease.

\section{Health check up}

The results of the study on the healthy lifestyle of FKIP Undana Penjaskesrek students during the covid 19 pandemic based on the health examination factor, the lowest score (minimum) 2, the highest score (maximum) 8, average (mean) 5.78, median (median) 6.00, frequently occurring value (mode) 6, standard deviation (SD) 1.230. 


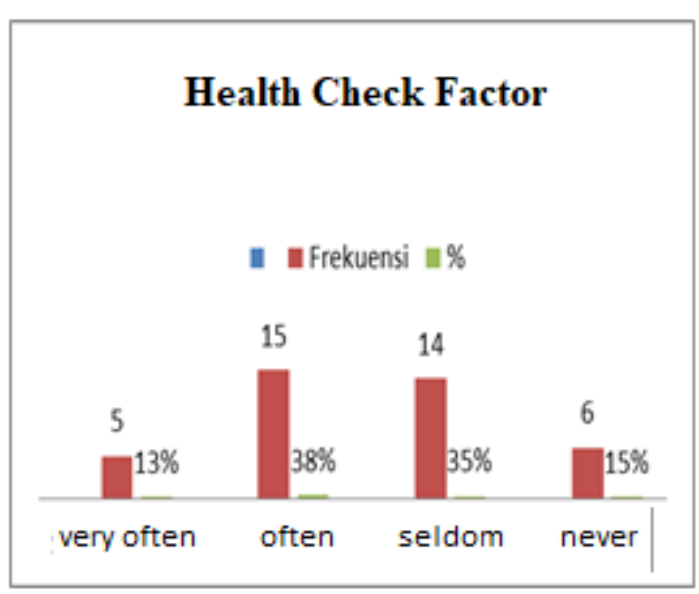

Figure 9. Health Check Factor Bar Chart

Based on the picture above, it shows that the healthy lifestyle of FKIP Undana Penjaskesrek students during the COVID-19 pandemic, the health check factors are in the "never" category at $10 \%$ (4 students), "rarely" at 20\% (8 students), "often" by $65 \%$ (26 students), "often" by $5 \%$ (2 students). Based on the average score, which is 6.00 , the healthy lifestyle of the FKIP Undana Penjaskesrek students is a factor of "Frequent" health checks.

\section{DISCUSSION}

This study aims to determine the healthy lifestyle of FKIP Undana Penjaskesrek students during the covid 19 pandemic, which was expressed by a questionnaire totaling 43 items, and divided into eight factors, namely (1) Maintaining cleanliness, (2) Healthy food, (3) How to regular life (4) Increase endurance and physical opportunities (5) Avoid the occurrence of disease (6) Increase the level of intelligence and spirituality (7) equip the house with facilities that guarantee a healthy life (8) Health checks. Based on the results of the study, it showed that the healthy lifestyle of FKIP Undana Penjaskesrek students during the covid 19 pandemic was in the "often" category in implementing a healthy lifestyle during the covid 19 pandemic.

A simple healthy lifestyle is to live daily life in a good way and pay attention to health factors, so that it becomes a healthy routine. Applying good habits in creating healthy living conditions and avoiding bad habits that can interfere with health is one of the descriptions of activities or activities that are supported by desires and interests and how our minds can live and interact with the surrounding environment.

In detail the healthy lifestyle in the Physical Education and Health Center of FKIP Undana, based on factors, namely maintaining health, healthy food, regular life, increasing body resistance and physical opportunities, avoiding disease, increasing intelligence and spiritual levels, and completing facilities that ensure healthy living. , and health checks can be explained as follows:

\section{Factors to maintain cleanliness}

The healthy lifestyle of FKIP Undana Penjaskesrek students during the COVID-19 pandemic was based on the factor of maintaining cleanliness in the "Frequent" category. This can be caused because students are aware of the importance of implementing a healthy lifestyle, especially in the midst of the covid 19 pandemic as it is today. Efforts to maintain body hygiene such as bathing, brushing teeth, and cleaning clothes from dirt and dust, while the environment, such as throwing garbage in its place, keeps the house clean. and the school environment are small things that can have a big impact on student health.

\section{Healthy food factors}

The function of food for the body is to reduce and prevent hunger, replace damaged body cells, for body growth, as a source of energy, and help cure disease. In addition to food, which must be 
considered is the drink. Drinking enough water contains minerals that the body needs. Healthy drinking water also means drinking water that is free from germs and toxins. If you sweat a lot and urinate a lot, the amount of water you drink should be increased so that the body does not become dehydrated. The function of water for the body is as a building material, as a regulator, and as a body heat regulation or body temperature.

\section{The factor of a regular way of life} According to Muhajir (2016: 282), regular life includes sleeping, working and resting regularly and doing recreation during holidays. Sleep should be at night. The day is 6 hours long. Sleep is the best way to get rest. If you don't get enough sleep, your health can be disrupted. Few people can live with a lack of sleep. As a result, lack of sleep in the body is felt, but over time the consequences will be felt. Common symptoms of lack of sleep include: droopy eyelids, pale, gloomy face and pale, weak body, lack of enthusiasm for work, laziness, and others.

4.Factors to increase endurance and physical opportunities

The healthy lifestyle of FKIP Undana Penjaskesrek students during the COVID-19 pandemic was based on factors of increasing body resistance and physical opportunities in the "Frequent" category. This could be because the community and children have begun to be aware of the importance of vaccination to increase immunity and prevent various diseases. Besides that, physical health is also very influential for the freshness of the body so that health is maintained. According to the Regulation of the Minister of Health of the Republic of Indonesia No. 12 of 2017 Article 1 paragraph 2 Vaccines are biological products containing antigens in the form of dead or living microorganisms that are attenuated, still intact or parts of it, or in the form of microorganism toxins that have been processed into toxoids or recombinant proteins, which added with other substances, which when given to a person will cause active specific immunity against certain diseases.

5. Factors increase to avoid the occurrence of disease

Avoiding disease is very easy for us to do, but it depends on the individual being diligent or not. For example, a house has a bathroom. If the owner is diligent and understands health, then the bathroom will be cleaned within an interval of a certain time. Water that is long remembered will easily become a nest for mosquitoes to breed.

6 . Factors that increase intelligence and spirituality

Factors that increase intelligence and spirituality in the "Frequent" category. This can be caused because students have started reading diligently to add insight and have had enough spiritual food so that they always obey religious teachings. The broad insight was used for ourselves to be wise in making decisions. For example, maintaining personal health by complying with several health rules. Spiritual health, one of which is obeying the rules of the beliefs he adheres to, such as worshiping, obeying the prohibition on doing haram.

7. Factors for improving the facilities that ensure a healthy life

Factors complementing facilities that ensure healthy living in the "Frequent" category. This can be because students already understand the benefits of completing facilities that ensure a healthy life. the existence of a good place to dispose of garbage and waste water, the existence of first aid kits to deal with accidents/illness. 


\section{Health check factors}

The healthy lifestyle of FKIP Undana Penjaskesrek students during the COVID-19 pandemic was based on health check factors in the "Frequent" category. These results can be interpreted that students already have an awareness of the importance of the pattern of health checks against illness and disease, namely how students carry out health maintenance, disease prevention, drug search and health recovery..

\section{CONCLUSION}

Based on the results of data analysis and discussion, it can be concluded that the healthy lifestyle of FKIP Undana Penjaskesrek students during the COVID-19 pandemic was in the "never" category by $15 \%$ (6 students), "rarely" by 35\% (14 students), " often" by $38 \%$ (15 students), "often" by 13\% (5 students). Based on the average score, which is 139.58 , the healthy lifestyle of FKIP Undana Penjaskesrek students is in the "frequent" category. In the sense that the FKIP Undana Penjaskesrek students during the covid 19 period often apply a healthy lifestyle.

Factors that are less dominant in the healthy lifestyle of FKIP Undana Penjaskesrek students need to be considered and solutions are sought so that these factors are more helpful in improving the lifestyle of FKIP Undana Penjaskesrek students.

\section{REFERENCES}

Arif, Y. (2020). Identifikasi Pemanfaatan Lingkungan Sekolah Sebagai Sumber Belajar Dalam Kegiatan Outbond. Journal Of Sport (Sport, Physical Education, Organization, Recreation, And Training). Https://Doi.Org/10.37058/Sport.V4i2.2
071

Arifin, Z. (2017). Kriteria Instrumen Dalam Suatu Penelitian. Jurnal Theorems (The Original Research Of Mathematics).

Arikunto, S. (2013). Prosedur Penelitian Atau Pendekatan Praktik. Cet Xv.

Intan, T., Hasanah, F., Wardiani, S. R., \& Handayani, V. T. (2021). Peningkatan Kualitas Hidup Di Masa Pandemi Covid-19 Dengan Penerapan Pola Hidup Sehat. Jurdimas (Jurnal Pengabdian Kepada Masyarakat) Royal. Https://Doi.Org/10.33330/Jurdimas.V4i 1.834

Isnayati, Ardana, I. G. N., Yulianti, D., \& Sarah. (2020). Upaya Meningkatan Kesehatan Masyarakat Desa Tanjung Mekar Melalui Perilaku Hidup Bersih Dan Sehat (Phbs) Di Rumah Tangga. Jurnal Kreativitas Pengabdian Kepada Masyarakat (Pkm).

Nopiyanto, Y. E., Raibowo, S., Sugihartono, T., \& Yarmani, Y. (2020). Pola Hidup Sehat Dengan Olahraga Dan Asupan Gizi Untuk Meningkatkan Imun Tubuh Menghadapi Covid-19. Dharma Raflesia: Jurnal Ilmiah Pengembangan Dan Penerapan Ipteks. Https://Doi.Org/10.33369/Dr.V18i2.13 008

Notoatmodjo. (2018). Metodologi Penelitian Kesehatan. Jakarta: Rineka Cipta. Notoatmodjo, S. (2018). Metodologi Penelitian Kesehatan. Jakarta: Rineka Cipta.

Noviasty, R., \& Susanti, R. (2020). Perubahan Kebiasaan Makan Mahasiswa Peminatan Gizi Selama Masa Pandemi Covid 19. Jurnal Kesehatan Masyarakat Mulawarman (Jkmm). Https://Doi.Org/10.30872/Jkmm.V2i2.5 079

Permenkes. (2017). Peraturan Menteri Kesehatan 2017. Peraturan Menteri Kesehatan Republik Indonesia Nomor 9 Tahun 2017 Tentang Apotek.

Rahmawati, M. (2020). Survei Minat, Motivasi Dan Kesadaran Hidup Sehat Masyarakat Dalam Mengikuti Olahraga Rekreasi Melalui Car Free Day Di Kota .... Indonesian Journal For Physical Education And ....

Saputra, S. A. (2020). Menjaga Imunitas Dan 
Kesehatan Tubuh Melalui Olahraga Yang Efektif. Prosiding Seminar Nasional Pendidikan Stkip Kusuma Negara Ii.

Setiati, S., \& Azwar, M. K. (2020). Covid-19 And Indonesia. Acta Medica Indonesiana.

Sugiono. (2016). Metode Penelitian Kuantitatif, Kualitatif Dan R\&D. Bandung: Alfabeta.

Sugiyono. (2017). Sugiyono, Metode Penelitian. Penelitian.

Wulandari, I. M. (2020). Peran Guru Mengoptimalkan Unit Kesehatan Sekolah Untuk Melakukan Pencegahan Covid-19. Edukatif: Jurnal Ilmu Pendidikan.

Https://Doi.Org/10.31004/Edukatif.V2i 1.88

Yulinda Sari, R., Andoko, A., \& Wulandari, A. (2020). Efektivitas Pendidikan Kesehatan Menggunakan Metode Pendidikan Individual Tentang Pengetahuan Pola Makan Pada Penderita Hipertensi Di Wilayah Kerja Puskesmas Rawat Inap Banjar Agung Kabupaten Lampung Selatan. Malahayati Nursing Journal. Https://Doi.Org/10.33024/Manuju.V2i4 .1633 